\title{
Diagnostic value of serum angiotensin converting enzyme activity in lung diseases
}

\author{
K UMAR ASHUTOSH and JOHN F. H. KEIGHLEY \\ Pulmonary Disease Section, Veterans Administration Hospital, Syracuse, New York 13210 \\ and Department of Medicine, State University of New York, Upstate Medical Center
}

\begin{abstract}
Ashutosh, K. and Keighley, J. F. H. (1976). Thorax, 31, 552-557. Diagnostic value of serum angiotensin converting enzyme activity in lung diseases. Serum angiotensin converting enzyme (ACE) activity was measured in 10 patients with early active sarcoidosis, nine patients with inactive or resolving sarcoidosis, 10 patients with malignant pulmonary neoplasms, eight patients with miscellaneous lung diseases, and 18 control subjects with no known pulmonary disease. The serum ACE activity, expressed in units/ $\mathrm{mi}_{\mathrm{i}}$, in control subjects $(5 \cdot 88 \pm 1.84)$, was no different from the values obtained in patients with inactive or resolving sarcoidosis $(6 \cdot 85 \pm 2 \cdot 48)$ or miscellaneous lung diseases $(4 \cdot 61 \pm$ 3.20). However, the ACE activity was found to be markedly raised in patients with early active sarcoidosis (13.49 \pm 2.52$)$, and there was no overlap with control values. The patients with pulmonary neoplasms had significantly lower values of serum ACE activity than the control subjects $(2 \cdot 80 \pm 3 \cdot 30)$.

Serum ACE activity did not correlate with blood pressure though a positive correlation $(r=0.51)$ existed with age in control subjects.

We conclude that a significant rise in serum ACE activity occurs in active sarcoidosis, but not in inactive or resolving sarcoidosis or in miscellaneous lung diseases. Its fall in lung tumours is also significant but of lesser diagnostic specificity. Serum ACE activity can be a useful diagnostic test for sarcoidosis and may also help in following the activity of the disease.
\end{abstract}

Conversion of angiotensin-I, a relatively inactive decapeptide, to angiotensin-II, a potent octapeptide, is one of the major metabolic functions of the lung ( $\mathrm{Ng}$ and Vane, 1967). This is brought about by the angiotensin converting enzyme (ACE), which releases the carboxy-terminal dipeptide, His-Leu, from angiotensin-I (Fig. 1) (Skeggs, Kahn, and Shumway, 1956). ACE is thought to be produced in the pulmonary vascular endothelium

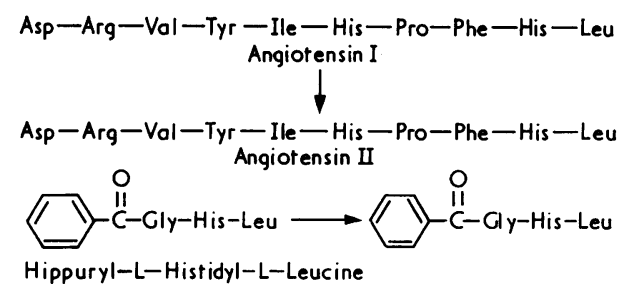

FIG. 1. Reactions catalysed by angiotensin-converting enzyme of lung. and is directly accessible to the pulmonary circula tion (Ryan, Smith, and Niemeyer, 1972).

Angiotensin converting enzyme in the periphera blood is identical with the lung enzyme (Huggins et al., 1970), although there is some evidence that the blood may also contain different varieties of ACE (Grandino and Paiva, 1974). Changes in serum ACE levels in lung diseases were initial reported by Lieberman (1974), who proposed rise in serum ACE levels as a confirmatory tesi for sarcoidosis, because he found raised levels of ACE in the sera of patients with untreated sae coidosis but normal levels in those who had been treated, and in patients with other forms of lung disease.

The present work was undertaken to verify and extend the above results and to evaluate the diage nostic value of this measurement in lung disease

\section{PATIENTS AND METHODS}

Sixty analyses were performed in 18 control sule 
jects and 36 patients with various lung diseases (Table I). The control subjects had no known lung disease or symptoms of lung or heart disease. All of them had had a normal chest radiograph within the last two years before the study. One subject had a fracture of the left ankle, three had hypertension, and all but two were smokers. One subject had a chronic cough and had had one episode of haemoptysis, but normal pulmonary function tests, normal lung scan, and a normal chest radiograph excluded significant disease.

There was no fixed time for drawing the blood for the study. In three control subjects blood was drawn both before and one hour after a heavy meal. In all other patients the blood was collected in the morning.

Only those patients in whom a definite diagnosis was obtained were included in the study. The criteria for making the diagnoses are as follows:

A diagnosis of sarcoidosis was made on the basis of a compatible clinical picture, chest radiograph, and definite demonstration of non-caseating granulomata in tissue obtained by biopsy, most commonly of a mediastinal lymph node. The last criterion was considered essential for making a diagnosis of sarcoidosis.

Sarcoidosis was considered inactive or resolving when (1) the patient was asymptomatic and the chest radiograph showed a definite resolution of the abnormal findings, (2) the chest radiograph showed a stage 2 or 3 sarcoidosis without any change over the last five years, or (3) the patient had noticed the disappearance of the initial symptoms over the last six months and the chest radiograph and lymph node biopsy showed a large component of fibrosis, calcification, or both. Each situation was seen in three patients. A diagnosis of early or active sarcoidosis was made when the symptoms were recent or progressive, the chest radiograph showed stage 1 or 2 sarcoidosis, and the biopsy did not show predominant fibrosis. The different stages of sarcoidosis have been defined and discussed by others and will not be repeated here (Sharma, 1975).

Tuberculosis was diagnosed on the basis of typical radiographic findings and the presence of Mycobacterium tuberculosis in the sputum on culture. Chronic airways obstruction was diagnosed by the characteristic radiological findings and pulmonary function tests. Acute respiratory failure (ARF) was defined on the basis of the arterial blood gas analyses showing a PaO: of less than $7.98 \mathrm{kPa}(60 \mathrm{mmHg})$ with or without an elevation of Paco.. All other conditions required a tissue diagnosis.

\section{METHOD OF ANALYSIS}

Ten millilitres of venous blood was allowed to clot and the serum was collected and stored in a refrigerator. All analyses were made within five days of collection. The assay method of Cushman and Cheung (1971), as modified by Lieberman (1975), was used. The method depends upon the ability of

T A B L E I

AGE, SEX. AND DIAGNOSES OF SUBJECTS IN THE DIFFERENT DIAGNOSTIC GROUPS

\begin{tabular}{|c|c|c|c|c|}
\hline Diagnostic Group & Diagnosis & $\begin{array}{l}\text { No. of } \\
\text { Subjects }\end{array}$ & $\begin{array}{c}\text { Sex } \\
(\mathbf{M}: F)\end{array}$ & Mean Age $\doteqdot$ SD, Range \\
\hline 1 Controls & $\begin{array}{l}\text { Normal, non-smokers } \\
\text { smokers } \\
\text { Old calcified granuloma } \\
\text { Hypertension } \\
\text { Iron-deficiency anemia } \\
\text { Total }\end{array}$ & $\begin{array}{r}2 \\
10 \\
1 \\
4 \\
1 \\
18\end{array}$ & $9: 9$ & $46 \cdot 0: 20 \cdot 3.20-85$ \\
\hline 2 Pulmonary tumours & $\begin{array}{l}\text { Primary-squamous cell } \\
\begin{array}{l}\text { oat cell } \\
\text { anaplastic large }\end{array} \\
\text { Metastatic- malignant melanoma } \\
\begin{array}{l}\text { adeno carcinoma of colon } \\
\text { Total anaplastic carcinoma oesophagus }\end{array}\end{array}$ & $\begin{array}{r}5 \\
1 \\
1 \\
1 \\
1 \\
1 \\
10\end{array}$ & $9: 1$ & $61 \cdot 3 \div 14 \cdot 7.48-81^{1}$ \\
\hline 3 Sarcoidosis & $\begin{array}{l}\text { Active } \\
\text { Inactive } \\
\text { Total }\end{array}$ & $\begin{array}{r}10 \\
9 \\
19\end{array}$ & $\begin{array}{l}7: 3 \\
7: 2\end{array}$ & $\begin{array}{l}29 \cdot 57-9 \cdot 68,22-451 \\
39 \cdot 38 \div 11 \cdot 25,27-56\end{array}$ \\
\hline 4 Miscellaneous & $\begin{array}{l}\text { Pulmonary tuberculosis } \\
\text { Chronic airways obstruction with acute respiratory failure } \\
\text { UIP with fibrosis } \\
\text { Hodgkin's disease } \\
\text { Histoplasmosis-coin lesion } \\
\text { Granulomatous iritis and tuberculosis } \\
\text { Total }\end{array}$ & $\begin{array}{l}3 \\
2 \\
1 \\
1 \\
1 \\
1 \\
9\end{array}$ & $9: 0$ & $52 \cdot 6: 14 \cdot 5,32-79$ \\
\hline
\end{tabular}

'Statistically significant difference from control subjects in age. 
the serum ACE to liberate hippuric acid from Hippuryl-L-histidyl-L-leucine (obtained from Cyclo Chemical, Los Angeles, California) (Fig. 1). The details of the assay methodology have been described elsewhere and will not be repeated here (Lieberman, 1975).

ACE activity was expressed in units per millilitre. One unit is defined as the activity producing 1 nanomole of hippuric acid from the substrate at $37^{\circ} \mathrm{C}$ in one minute in the standard assay system.

\section{RESULTS}

No correlation was found between blood pressure and ACE activity. However, a statistically significant correlation $(r=0.51)$ was found between age and ACE activity, the ACE activity increasing with age (Fig. 2).

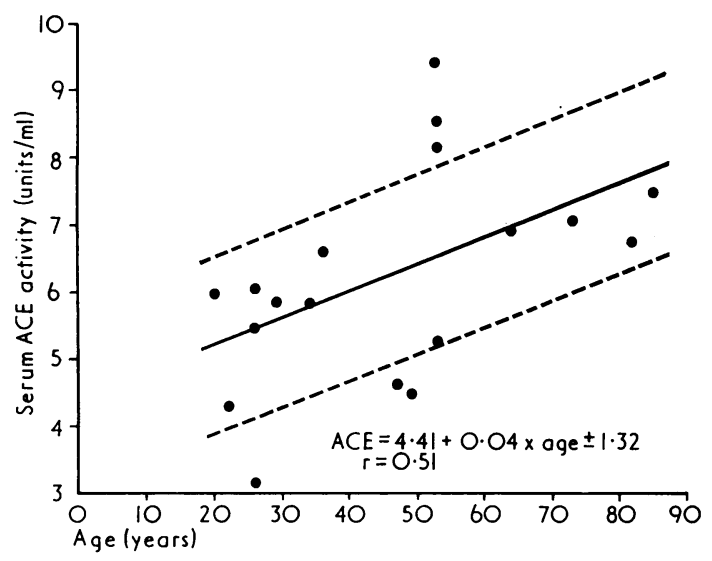

FIG. 2. Relation between age and serum ACE. Broken lines represent \pm 1 standard deviation from the regression line (solid).

In three normal subjects, the serum ACE activity was measured before and after a heavy meal, and no difference was found. The important finding was the serum ACE activity in the various diagnostic categories (Table II; Fig. 3). The serum ACE activity was increased in all patients with early active sarcoidosis. There was no overlap between the serum ACE activity levels in the patients with active sarcoidosis and the control subjects, or patients with other disease conditions, including Hodgkin's disease, tuberculosis, and interstitial pneumonia. Patients with inactive or resolving sarcoidosis had serum ACE levels similar to those in the control subjects. The highest levels
T A B L E I I

SERUM ACE ACTIVITY IN DIFFERENT

\begin{tabular}{|c|c|c|c|}
\hline Diagnostic Group & Number & $\begin{array}{c}\text { ACE Activity } \\
- \text { Mean } \pm 1 S D \\
\text { (units/ml) }\end{array}$ & $\begin{array}{c}\text { P Value } \\
\text { (Student's } \\
t \text { test } \\
\text { compared to } \\
\text { control) }\end{array}$ \\
\hline $\begin{array}{l}\text { Control } \\
\text { Pulmonary tumours } \\
\text { Miscellaneous } \\
\text { Sarcoidosis-active } \\
\quad \text { inactive }\end{array}$ & $\begin{array}{r}21 \\
10 \\
9 \\
12 \\
9\end{array}$ & $\begin{array}{r}5 \cdot 88 \pm 1 \cdot 84 \\
2 \cdot 80 \pm 3 \cdot 30 \\
4 \cdot 61 \pm 3 \cdot 20 \\
13 \cdot 49 \pm 2 \cdot 52 \\
6 \cdot 85 \pm 2 \cdot 48\end{array}$ & $\begin{array}{l}<0.01 \\
\text { NS } \\
<0.001 \\
\text { NS }\end{array}$ \\
\hline
\end{tabular}

NS-not significant.

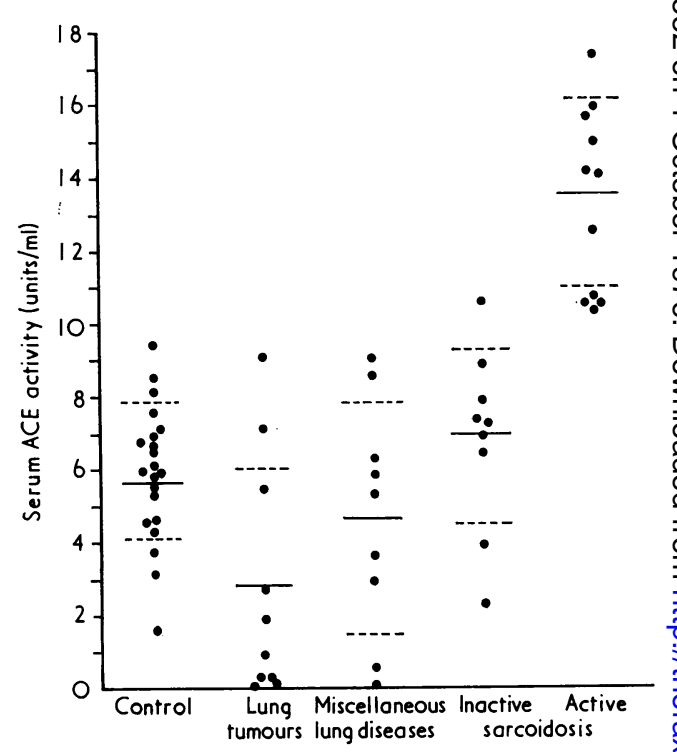

FIG. 3. Serum ACE levels in different diagnost categories. Solid lines represent the mean and broken lines \pm 1 standard deviation from the mean.

in this group were found in three patients who hac had sarcoidosis for less than six months and hagl persistent hilar lymphadenopathy but neverthele were considered to have resolving disease because of a marked amelioration of symptoms. One of these patients was receiving treatment with com ticosteroids, one with acetyl salicylic acid, while ga third was improving without any medication.

More than one estimation of serum AC activity was made in two patients with active sas. coidosis. In one patient, the second estimation was made three months after the initial estimation. The patient was not on any therapy, there was $r \vec{B}$ clinical or radiological evidence of resolution of the disease, and the symptoms had persisted. The sarcoidosis was considered still active and the 
serum ACE activity was found to be higher (15.8 units $/ \mathrm{ml})$ than the first measurement $(10.4$ units/ $\mathrm{ml}$ ). In another patient, the initial ACE activity $(14.9$ units $/ \mathrm{ml})$ was unchanged when measured again after two months $(14 \cdot 1$ units $/ \mathrm{ml})$. The patient was not on any treatment and had developed worsening symptoms and physical signs. The chest radiograph was unchanged. After the second study of serum ACE activity the patient was started on prednisone, which resulted in a disappearance of symptoms and almost complete resolution of the physical signs. The chest radiograph showed marked diminution in the size of the hilar and paratracheal nodes. The disease was considered to be resolving at this stage and the serum ACE activity had fallen to 10.6 units $/ \mathrm{ml}$.

Serum ACE activity was found to be significantly lower in patients with malignant tumours of the lung than in the control subjects. Though taken together as a group, there was a wide range in the values of the serum ACE activity; in five of these patients it was less than $1 \mathrm{unit} / \mathrm{ml}$. These patients were characterized by extensive involvement of the pulmonary parenchyma. The tumour was squamous-cell carcinoma in two patients, oatcell carcinoma in one, and metastatic carcinoma from the colon and from the oesophagus in one patient each. On the other hand, the three patients with values of serum ACE activity above 3 units/ $\mathrm{ml}$ had much less involvement of the pulmonary parenchyma.

\section{DISCUSSION}

Our results show a marked increase in serum ACE activity in patients with early active sarcoidosis without any overlap between the values in early active sarcoidosis and in the control subjects, or in the patients with other lung diseases. In patients with inactive or resolving sarcoidosis, with or without therapy, the serum ACE activity is similar to the control values.

A lower mean serum ACE level was found in the patients with pulmonary tumours, more extensive involvement of the lung parenchyma being associated with a greater fall in the serum ACE level. However, the overlap with controls and with other diseases was such that the ACE activity could not be of much diagnostic value in a given case.

The increase of serum ACE level in active sarcoidosis and its fall to control values in inactive or treated sarcoidosis has recently been confirmed by Lieberman (1975). He reported serum ACE levels of $13.65 \pm 2.26$ units $/ \mathrm{ml}$ in cases of active sarcoidosis, $6 \cdot 89 \pm 2 \cdot 19$ units $/ \mathrm{ml}$ in patients with sarcoidosis who were on steroids, and $7 \cdot 33 \pm 2 \cdot 48$ units $/ \mathrm{ml}$ in patients in whom sarcoidosis was considered dormant. These are almost identical with the results obtained by us. Also, significantly lower serum ACE levels were observed in patients with lung tumours by Lieberman, which is in agreement with our study.

The control subjects in Lieberman's study had higher serum ACE levels (7.60 $\pm 2 \cdot 01)$ than reported by us. Furthermore, in our study, no difference was noted in the serum ACE levels between the two sexes, and the serum ACE level appeared to rise with increasing age. On the other hand, Lieberman found significantly higher values in males compared to females, and a fall in serum ACE levels with age. His data show that the fall in serum ACE level occurs up to the age of 20-30 years and, after that, the level remains unchanged or may even show a slight rise. The difference in serum ACE levels between male and female subjects also is more marked under the age of 20 years. The different age composition of the control population in the two studies may account for the difference in the results, as the subjects in Lieberman's study were much younger than ours.

Also, the significant fall in patients with chronic airways obstruction and with tuberculosis, compared to the control subjects, found by Lieberman was not observed in our study. Further work is required to clarify this point.

At the present time a diagnosis of sarcoidosis depends on finding multisystem disease by the demonstration of non-caseating granulomata in tissues obtained by biopsy. The Kveim test, too, depends upon a demonstration of granulomata in the skin biopsy. If our results are confirmed in a larger and more varied patient population, then estimation of the serum ACE activity will simplify the diagnosis of sarcoidosis and also help in the follow-up of the activity of the disease.

No explanation for the increase in the serum ACE in sarcoidosis has been proposed. As the method for measuring the ACE activity in the present study depended upon the splitting of the terminal dipeptide from the substrate used, the possibility exists that the higher values in patients with sarcoidosis represented merely a rise in nonspecific serum peptidases which has been known to occur in various acute stress situations (Abderhalden, 1961). We do not believe that to be the case for two reasons. First, the method used by us to measure ACE activity has been shown to reflect accurately the true ACE activity and not non-specific peptidase activity (Cushman and 
Cheung, 1971), and, secondly, ACE activity was not found to be increased in the various acute stress situations in our study, ie, acute respiratory failure, shock, tuberculosis, etc.

The amount of many substances rises in the serum of patients with sarcoidosis. An increase in the quantity of IgG in sarcoidosis is well known (James, Neville, and Walker, 1975). Pascual, Gee, and Finch (1973) reported a rise in serum lysozyme activity in sarcoidosis during its active stage. Unlike a rise in serum ACE activity, which seems to be specific for sarcoidosis, serum lysozyme activity was increased in leukaemias and bacterial infections, thereby reducing the diagnostic value of the test. The reason for the rise in serum lysozyme activity remains unclear.

A rise in serum ACE activity might occur because of an increased formation of ACE by the endothelial cells of the pulmonary capillaries, or secondary to an increase in number of the capillaries themselves. It can be postulated that a lesion which destroyed the lung, resulting in decreased vascularity, or a lesion which infiltrated the lung and thereby replaced the pulmonary capillaries with an abnormal blood supply, would result in a fall in the serum ACE activity, while a lesion stimulating the proliferation of the pulmonary capillaries, or inducing an overactivity of the pulmonary endothelial cells, would result in a higher serum ACE activity. Sarcoidosis has now been accepted as being an immune-reaction, and increased proliferation of the lymphocytes and plasma cells accumulating in the sarcoidosis lesions has been demonstrated by Ghose, Landrigan, and Asif (1974). The same authors have shown that the sarcoid granuloma contains marked extravascular deposits of immunoglobulins of IgG type, and C3, along with a smaller amount of IgM. This phenomenon has not been commonly seen in some other immunological lung diseases such as extrinsic allergic alveolitis and diffuse interstitial pneumonia. The immunoglobulins reacting with pulmonary endothelial cells might result in injury to those cells with an escape of the ACE in the peripheral circulation, or might induce overactivity of these cells.

Recently, serum and lung ACE activities have been shown to rise in parallel, in response to chronic alveolar hypoxia in experimental animals (Molteni et al., 1974), possibly due to pulmonary vascular changes caused by the hypoxia. Reduced alveolar oxygen tension might have been responsible for the small rise in the serum ACE activity seen with increasing age in the control subjects.
Increased closure of the dependent small airwaye in the tidal volume range, with a subsequent fat in the oxygen tension of these alveoli, is a well known concomitant of increasing age (Terma and Newton, 1964; Holland et al., 1968).

In another observation, lymph nodes frorf? patients with sarcoidosis were shown to have $\vec{\nexists}$ higher ACE level compared to the ACE levels $\overrightarrow{i n}$ normal, adenocarcinomatous, and chronic reactive inflammatory lymph nodes (Silverstein et al 1975). This may be suggestive of increased forma tion of the ACE in the sarcoidosis lymph nodes. The exact cause for this finding is unclear.

We are grateful to R. Bowman, Ph.D., fcr helping set up the assay system and allowing the use of the laboratory facilities; to Dr. W. Williams for valuabto comments and criticism; and to Miss Jean Ward for her patient help in the preparation of the manuscrip?

This work was supported by a grant from the Veterans Administration Research Fund.

\section{REFERENCES}

Abderhalden, R. (1961). Clinical Enzymology, tran lated by $\mathbf{P}$. Oesper. Van Nostrand, Princetof New Jersey.

Cushman, D. W. and Cheung, H. S. (1971). Spectro photometric assay and properties of the angio tensin-converting enzyme of rabbit lun. Biochemical Pharmacology, 20, 1637.

Ghose, T., Landrigan, P., and Asif, A. (1974). Loca厚 zation of immunoglubulin and complement pulmonary sarcoid granulomas. Chest, 66, 264.

Grandino, A. and Paiva, A. C. M. (1974). Isolatiợ of angiotensin-converting enzyme withogt kininase activity from hog and guinea pig plasma. Biochemica et Biophysica Acta, 36, 113.

Holland, J., Milic-Emili, J., Macklem, P. T., aß̊d Bates, D. V. (1968). Regional distribution of pulmonary ventilation and perfusion in elder $\Phi$ y subjects. Journal of Clinical Investigation, 81.

Huggins, C. G., Corcoran, R. J., Gordon, J. S. Henry, H. W., and John, J. P. (1970). Kinet of the plasma and lung Angiotensin I converting enzymes. Circulation Research, 26 and Supplement, 1, 93.

James, D. G., Neville, E., and Walker, A. (1975). Immunology of sarcoidosis. American Journgl of Medicine, 59, 388.

Lieberman, J. (1974). A new confirmatory test for sarcoidosis. Serum angiotensin converting enzyme: effect of steroids and chronic lum disease. American Review of Respiratory Disea 109, 743 (Abstract).

Lieberman, J. (1975). Elevation of serum angiotens converting-enzyme (ACE) level in sarcoidosis. American Journal of Medicine, 59, 365. 
Molteni, A., Zakheim, R. M., Mullis, K. B., and Mattioli, L. (1974). The effect of chronic alveolar hypoxia on lung and serum angiotensin I converting enzyme activity. Proceedings of the Society for Experimental Biology and Medicine, 147, 263.

$\mathrm{Ng}, \mathrm{K}$. K. F. and Vane, J. R. (1967). Conversion of Angiotensin I to Angiotensin II. Nature (Lond.), 216, 762.

Pascual, R. S., Gee, J. B. L., and Finch, S. C. (1973). Usefulness of serum lysozyme measurement in diagnosis and evaluation of sarcoidosis. New England Journal of Medicine, 289, 1074.

Ryan, J. W., Smith, U., and Niemeyer, R. S. (1972). Angiotensin I: metabolism by plasma membrane of lung. Science, 176, 64.

Sharma, O. P. (1975). Intrathoracic sarcoidosis. In Sarcoidosis: A Clinical Approach, p. 30. C. C. Thomas, Publisher, Springfield, Illinois.
Silverstein, E., Friedland, J., Lyons, H., and Gourin, A. (1975). Elevated angiotensin converting enzyme activity in non-necrotizing granulomatcus lymph nodes in sarcoidosis. Clinical Research, 23, 352A.

Skeggs, L. T., Jr, Kahn, J. R., and Shumway, N. P. (1956). The preparation and function of hypertensin-converting enzyme. Journal of Experimental Medicine, 103, 295.

Terman, J. W. and Newton, J. L. (1964). Changes in alveolar and arterial gas tensions as related to altitude and age. Journal of Applied Physiology, 19, 21.

Requests for reprints to: Dr. K. Ashutosh, Pulmonary Disease Section, Veterans Administration Hospital, Syracuse, New York 13210, USA. 